\title{
Correction to: Glyconanoparticles as tools to prevent antimicrobial resistance
}

\author{
Laura Morelli $^{1} \cdot$ Laura Polito $^{2} \cdot$ Barbara Richichi $^{3} \cdot$ Federica Compostella $^{1}$ (iD \\ (C) (c) The Author(s) 2021
}

\section{Correction to: Glycoconjugate Journal. https://doi.org/10.1007/s10719-021-09988-6}

The original article has been corrected. The correct article title should be "Glyconanoparticles as tools to prevent antimicrobial resistance" instead of "Glyconanano particles as tools to prevent antimicrobial resistance.

Open Access This article is licensed under a Creative Commons Attribution 4.0 International License, which permits use, sharing, adaptation, distribution and reproduction in any medium or format, as long as you give appropriate credit to the original author(s) and the source, provide a link to the Creative Commons licence, and indicate if changes were made. The images or other third party material in this article are included in the article's Creative Commons licence, unless indicated otherwise in a credit line to the material. If material is not included in the article's Creative Commons licence and your intended use is not permitted by statutory regulation or exceeds the permitted use, you will need to obtain permission directly from the copyright holder. To view a copy of this licence, visit http://creativecommons.org/licenses/by/4.0/.

Publisher's note Springer Nature remains neutral with regard to jurisdictional claims in published maps and institutional affiliations.

This article belongs to the Topical Collection: Glycoconjugate vaccines: classic and novel approaches

The online version of the original article can be found at https://oi.org/ 10.1007/s10719-021-09988-6

Federica Compostella

federica.compostella@unimi.it

1 Department of Medical Biotechnology and Translational Medicine, University of Milan, Via Saldini 50, 20133 Milan, Italy

2 National Research Council, CNR-SCITEC, Via G. Fantoli 16/15, 20138 Milan, Italy

3 Department of Chemistry 'Ugo Schiff', University of Florence, Via della Lastruccia 13, 50019 Sesto Fiorentino, FI, Italy 